\title{
DETECTION OF PSYCHIATRIC MORBIDITY IN THE PRIMARY MEDICAL CARE SETTING IN BRAZIL*
}

Jair de Jesus Mari**:

Eduardo Iacoponi**

Paul Williams**

Oziris Simōes**

João Batista Teodoro Silva**

MARI, J. de J. et al. Detection of psychiatric morbidity in the primary medical care setting in Brazil. Rev. Saúde públ., S. Paulo, 21:501-7, 1987.

\begin{abstract}
The aims of this study were a) to assess the ability of primary care doctors to make accurate ratings of psychiatric disturbance and b) to evaluate the use of a case-finding questionnaire in the detection of psychiatric morbidity. The estudy took place in three primary care clinics in the city of São Paulo, Brazil, during a six-month survey. A time sample of consecutive adult attenders were asked to complete a case-finding questionnaire for psychiatric disorders (the Self Report Questionnaire - SRQ) and a subsample were selected for a semi-structured psychiatric interview (the Clinical Interview Schedule - CIS). At the end of the consultation the primary care doctors were asked to assess, in a standardized way, the presence or absence of psychiatric disorder; these assessments were then compared with that ratings obtained in the psychiatric interview. A considerable proportion of minor psychiatric morbidity remained undetected by the three primary care doctors: the hidden morbidity ranged from $22 \%$ to $79 \%$. When these were compared to those of the case-finding questionnaire, they were consistently lower, indicating that the use of these instruments can enhance the recognition of psychiatric disorders in primary care settings. Four strategies for adopting the questionnaire are described, and some of the clinical consequences of its use are discussed.
\end{abstract}

UNITERMS: Mental disorders, diagnosis. Mass screening, methods. Primary health care.

\section{INTRODUCTIÓN}

In Latin America as a whole there are many factors which are likely to be associated with a high prevalence of psychiatric morbidity in the population ${ }^{26}$. These include marked differences in wealth distribution among different social classes, the improvement in life expectancy and the expected fall in fertility rates, fast population growth (urbanization and industrialization) in already populated cities, inadequate housing facilities, changes in family structure, nutritional problems, the high rate of criminality and constant tension due to political instability. Psychiatric care is still hospital-oriented and the number of extramural facilities has probably not been sufficient to deal with the population needs.

The primary health care system is expanding in many countries, and the intention of health planners is usually to link psychiatric care into such developments ${ }^{37}$. However, many studies, mainly carried out in Europe and the United States, show that a considerable proportion (ranging from $30 \%$ to $60 \%$ ) of psychiatric disturbance remains unrecognized by the primary care doctor ${ }^{3}, 10,12,13,16,31,33$.

The aims of this study are: a) to assess the ability of primary care doctors to identify psychiatric disorders in primary care; b) to investigate the value of a case-finding questionnaire in assisting doctors to identify psychiatric disorders in their patients. To our knowledge, no previous research has been conducted on this topic in Latin America.

\section{METHOD}

The study was conducted in three primary care clinics in the city of $S$. Paulo from

* Partly supported by "Conselho Nacional de Desenvolvimento Científico e Tecnológico" - CNPq, by "Fundação de Amparo à Pesquisa do Estado de São Paulo" — FAPESP and the Division of Mental Health of the World Health Organization.

*:* Departamento de Psiquiatria da Escola Paulista de Medicina - Rua Botucatu, 740 - 04023 - São Paulo, SP - Brasil. 
September 1982 to February 1983. Two were health centres (Ladeira Rosa Health Centre and Barra Funda/Bom Retiro Health Centre) and the third was an outpatient clinic (providing primary rather than secondary care) in a general hospital (Hospital do Servidor Público Estadual de São Paulo).

Each of the primary care clinics was sam-pled on randomly-selected days twice each week. On the selected day, the unit was visited by a psychiatrist (J.J.M.) and a research assistant. At each clinic, an unduplicated timesample of consecutive attenders aged 16 or more years was asked to fill in a case-finding questionnaire for psychiatric disorders, the 20-item Self Report Questionnaire (SRQ) before seeing the primary care doctor. This instrument was designed by Harding e col. ${ }^{17}$ to study mental illness in primary care settings in developing countries. It was translated into eight languages for use in the WHO "Collaborative Study on Strategies for Extending Mental Health Care in Developing Countries"18. As part of this study, a Portuguese version of the SRQ was made available and it has been applied by Busnello and col. ${ }^{4}$ in Brazil. The SRQ has also been used in Senegal, Kenya, China and India ${ }^{6,8,9,32}$. Findings regarding the validity of this instrument in Brazil are given elsewhere ${ }^{29,30}$. The Portuguese version can be seen in Annex.

After the consultation, the primary care doctors were asked to rate the presence/ absence of psychiatric morbidity on a 5-point rating scale ${ }^{13}$. A subsample of patients was then selected for a semi-structured psychiatric interview using the Clinical Interview Schedule $(\mathrm{CIS})^{14}$. This is a semi-structured psychiatric interview developed to study psychiatric morbidity in general practice and community settings. The CIS has been found to be acceptably reliable in a variety of settings $s^{5,7,14}$ and the Portuguese version of this instrument proved to be both feasible and reliable for use in Brazil $^{25,27,28}$. Respondents scoring more than 12 were classified as 'cases' according to the criterion used in previous studies,19. All interviews were conducted 'blind', i.e., without knowledge of the other assessments.

\section{RESULTS}

Eight hundred and seventy five patients completed the case-finding questionnaire during the six months survey (the "total sample" - 291, 349 and 235 patients from Brasilandia, Servidor and Barra Funda, respectively). Eight patients were not included in the study: 7 presented with severe and acute illness and 1 refused to fill in the case-finding questionnaire. Two hundred and sixty patients were interviewed by the psychiatrist (the "interviewed subsample" - $-80,100$ and 80 patients from Brasilandia, Servidor and Barra Funda, respectively); only three of those selected refused to participate in the psychiatric interview. The interviewed subsample proved to be representative (in terms of psychiatric morbidity and sociodemographic variables) of the study sample: the results described here were obtained from this subsample ${ }^{25}$.

The true prevalence of psychiatric morbidity, according to the standardized interview, was $50 \%$ in Servidor, $47 \%$ in Barra Funda and $56 \%$ in Brasilandia, respectively. On the other hand, the conspicuous psychiatric morbidity (i.e. the proportion of patients regarded by the primary care doctor as exhibiting significant psychiatric morbidity) was $48 \%$ in Servidor, $10 \%$ in Barra Funda and $49 \%$ in Brasilandia (Table 1). It is clear, therefore, that three primary care doctors, as compared with the psychiatrist, underestimated the prevalence of psychiatric morbidity in their patients, although to a differing degree.

TABLE 1

Relationship between general practitioners' and psychiatrist's assessments of morbidity - Health Centres S. Paulo (Brazil), 1982/83.

\begin{tabular}{lccc}
\hline \multicolumn{1}{c}{$\begin{array}{c}\text { Health } \\
\text { Centres }\end{array}$} & Servidor & $\begin{array}{c}\text { Barra } \\
\text { Funda }\end{array}$ & Brasilândia \\
Index & & & \\
\hline $\begin{array}{l}\text { Estimated true } \\
\text { prevalence }\end{array}$ & $50 \%$ & $47 \%$ & $56 \%$ \\
$\begin{array}{l}\text { Conspicuous } \\
\text { morbidity }\end{array}$ & $48 \%$ & $10 \%$ & $49 \%$ \\
$\begin{array}{l}\text { Bias } \\
\begin{array}{l}\text { Accuracy } \\
\text { Identification }\end{array}\end{array}$ & 0.94 & 0.20 & 0.84 \\
index & $81 \%$ & $61 \%$ & $85 \%$ \\
\hline
\end{tabular}

* of cases

tof attenders

Goldberg and Huxley ${ }^{15}$ have described three indices (bias, accuracy and identification index) by which to measure general practitioners' identification of psychiatric disorder. Bias can be regarded as the doctor's general tendency to make, or avoid making, a psychiatric diagnosis, and is measured simply by the ratio of the conspicuous psychiatric morbidity to the estimated true prevalence. Table 1 shows that the values for the bias of the 
three study doctors were $0.94,0.20$ and 0.84 , respectively.

However, even if general practitioner and psychiatrist agree closely on the overall level of morbidity, it does not follow that the same patients will be identified as ill by the two. This notion is reflected in the concept of accuracy, which quantifies the extent of individual agreement. Goldberg and Huxley ${ }^{15}$ described the use of a rank order correlation coefficient (between GP assessments and screening questionnaire scores) as an indicator of accuracy, while Skuse e Williams ${ }^{33}$ used the overall agreement rate as the measure. Table 1 shows that the overall agreement rates between the three primary care doctors and the psychiatric assessment to be $81 \%, 61 \%$ and $85 \%$ for Servidor, Barra Funda and Brasilandia, respectively.

Measures of overall agreement do not discriminate between true positive and true negative agreement - in the present context, true positive agreement (i.e. the extent to which the general practitioner agrees with the psychiatrist on the identification of psychiatric cases) is much more important than true negative agreement (i.e. the extent to which they agree on the identification of normals). The identification index measures the ability of doctors to identify cases, and is analogous to the sensitivity (and is the complement of the hidden psychiatric morbidity). The figures for the three doctors were $78 \%, 21 \%$ and $65 \%$, respectively (Table 1 ). Thus, the physician in Barra Funda identified only one-fifth of the psychiatric morbidity which presented to him.

These findings raise the issue as to whether a self-report questionnaire would assist the doctors in their identification of psychiatric morbidity, and if so, what is the optimum strategy for its use. One method of studying this is to adopt a cost-benefit approach ${ }^{24,33,35^{*}}$.

As indicated above, a proportion of patients with psychiatric morbidity will not be identified as such. Conversely, some patients without psychiatric disorder will be wrongly labelled by the doctors. A cost is incurred by these false positives: this includes the cost of visiting the doctor, plus the cost, in terms of distress, of being falsely labelled a psychiatric case, plus the possible costs due to the real nature of the illness or complaint being unde- tected (e.g. pain, suffering, unnecessary investigations, time off work).

A cost is also incurred by the false negatives (i.e. the hidden psychiatric morbidity): this is equal in value but different in sign to the net benefit derived from accurate identification of the disorder (i.e. the cost of having one's psychiatric disorder missed is not receiving the benefit that would accrue if the disorder were correctly identified and treat$\mathrm{ed}^{35}$ ).

Consider now the introduction of a casefinding procedure - such as a self-report questionnaire - into the primary care clinic. It can be assumed that this in itself does not alter the values of cost and benefit, but the procedure will change the extent of misidentification.

The change in misclassification will depend, at least in part, on the way in which the results of the self-report questionnaire (adjusted on the basis of pre-existing validity data) are taken into account along with the clinical judgement of the general practitioner. Skuse and Williams ${ }^{33}$ described four strategies for case-finding. Strategy $I$ is the baseline - i.e., no case-finding procedure other than the GP's judgement, while strategy II is one in which only the result of the questionnaire is taken into account - the doctor either makes no assessment or ignores it. In strategies III and IV, both doctor's assessment and questionnaire result contribute information to the caseness decision: in strategy III, a patient is considered to be a phychiatric case if and only if he/she is so classified by both the questionnaire and the doctor (acting independently), while in strategy IV, a patient is considered to be a case if he/she is so classified by either the questionnaire or the primary care physician.

Table 2 shows the relevant results. If the doctors were to apply the screening test to those patients that (s)he regards as a psychiatric case (Strategy III), there would be ten more false negatives and ten fewer false positives (taking the three clinics together) - i.e. the overall net benefit is zero.

If Strategy IV (apply screening test only to those patients not regarded as a case by the doctors) were to be applied, then benefit would accrue to 46 patients and a cost would

* Including the work of G. Wilkinson and D. Q. Borsey - Screening for psychiatric disorders in patients with Diabetes Millitus, 1987. Unppublished. 
TABLE 2

The introduction of a case-finding procedure: cost-benefit considerations

\begin{tabular}{|c|c|c|c|c|}
\hline Health centres & Servidor & Barra Funda & Brasilândia & Total \\
\hline \multicolumn{5}{|l|}{ Strategy I - doctor only } \\
\hline False negatives & 11 & 31 & 16 & 58 \\
\hline False positives & 8 & 0 & 9 & 17 \\
\hline \multicolumn{5}{|l|}{ Strategy II - SRQ only } \\
\hline False negatives & 9 & 5 & 8 & 22 \\
\hline benefit* & 2 & 26 & 8 & 36 \\
\hline False positives & 9 & 6 & 11 & 26 \\
\hline $\cos t * *$ & 1 & 6 & 2 & 9 \\
\hline Benefit/cost ratio & $2: 1$ & $4.3: 1$ & $4: 1$ & $4: 1$ \\
\hline \multicolumn{5}{|l|}{ Strategy III - doctor and SRQ } \\
\hline False negatives & 18 & 31 & 19 & 68 \\
\hline benefit** & -7 & 0 & -3 & -10 \\
\hline False positives & 2 & 0 & 5 & 7 \\
\hline $\operatorname{cost}^{* *}$ & -6 & 0 & -4 & -10 \\
\hline Benefit/cost ratio & $1.1: 1$ & 1 & $0.7: 1$ & 1 \\
\hline \multicolumn{5}{|l|}{ Strategy IV - doctor or SRQ } \\
\hline False negatives & 2 & 5 & 5 & 12 \\
\hline benefit* & 9 & 26 & 11 & 46 \\
\hline False positives & 15 & 6 & 15 & 36 \\
\hline $\cos t * *$ & 7 & 6 & 6 & 19 \\
\hline Benefit/cost ratio & $1.2: 1$ & $4.3: 1$ & $1.8: 1$ & $2.4: 1$ \\
\hline
\end{tabular}

* Benefits $=$ the decrement in false negatives as compared with Strategy I.

* Costs $=$ the increment in false positives as compared with Strategy $\mathrm{I}$.

be incurred by 19 , i.e., a benefit to cost ratio of 2.4:1. However, the corresponding figures for Strategy II (apply screening test to all patients) would be 36 benefits and 9 costs, a ratio of $4: 1$. Thus, taking the three doctors together, Strategy II is the optimum (i.e. the one which maximises the benefit-to-cost ratio).

It can also be seen from Table 2 that the screening questionnaire - whether applied according to Strategy II or Strategy IV would be of most benefit to the Barra Funda doctor, whose false negative rate was the highest.

It could, with justification, be said that the numbers on which these findings are based are relatively small, so confidence in the selection of an optimum case-finding strategy will be low. The precision of the results of a decision analysis such as this is tested by means of sensitivity analysis ${ }^{34}$ a form of which has been devised for application to screening questionnaire data by Skuse and Williams ${ }^{33}$. Their method was applied to the present data, and Strategy II remained the optimum when tested over a wide range of levels of general practitioner performance.

\section{DISCUSSION}

Many studies of general practitioners' ability to detect psychiatric disorder have been conducted in Great Britain ${ }^{31}$, North America ${ }^{23}$, and, less frequently, in Western Europe'. To our knowledge, the present study is the first to address this topic from in a Latin American setting.

Our findings, from a heavily industrialized city in Brazil, are similar to those obtained in the First World studies. Thus, while the estimated true prevalence of psychiatric morbidity in the three clinics (as determined by a two-stage screening technique, using the Clinical Interview Schedule as the second stage criterion) ranged between $47 \%$ and $56 \%$ (of attenders), the rates of conspicuous psychiatric morbidity ranged from $10 \%$ to $49 \%$. Thus, each of the three primary care doctors underestimated the psychiatric morbidity of their patients, although to a varying degree. A number of factors, relating to the patient, the setting and the doctor, have been shown to influence the rates of identification (reviewed by Goldberg and Huxley ${ }^{15}$ ) but no data were 
collected to investigate this topic in the present study.

This study has demonstrated the utility of a questionnaire in case-finding with regard to psychiatric disorder in the primary care setting. Such questionnaires are cheap to use and easy to administer, and, as the results show, the potential benefits in terms of accuracy of identification of attenders, can be very real. Not surprisingly, the benefit in terms of numbers (as opposed to benefit/cost ratios) was greatest for the doctor with the highest level of hidden psychiatric morbidity (in the Barra Funda clinic). As Skuse and Williams ${ }^{33}$ found, the optimum strategy was one in which the screening questionnaire was applied to all attenders, irrespective of the primary care physicians' assessment (Strategy II).

The assumption underlying such as analysis is that accurate identification of the psychiatric morbidity is ipso facto useful, and to be encouraged. Johnstone and Goldberg ${ }^{22}$ in a study which is, to our knowledge, the only longitudinal prospective investigation of this topic, showed that it was. On the contrary, Hoeper and $\mathrm{col}^{20}$ showed that general practitioners were not always able to make use of the additional information made available by screening questionnaires. This topic urgently requires further investigation in a wide variety of nonspecialist settings.

However, the conditions of primary medical care in São Paulo are such that caution must be exercised before recommending that questionnaires be used for the routine detection of psychiatric morbidity. The workload is heavy, the training of general practitioners is such that they are poorly equipped to manage the spectrum of psychiatric morbidity that presents to them ${ }^{21}$ and specialist psychiatric care is readily accessible ${ }^{11}$. Thus, the possibility exists that the introduction of case-finding procedures will result in an "increased throughput"36 of patients to the specialist mental health services, and a consequent increase in inappropriate referral. The use of questionnaires alone is therefore not enough: attention must be paid to undergraduate and postgraduate training of medical and other primary care personnel, and consideration must be given to the role of the psychiatrist in facilitating ways of improving the psychiatric skills of primary care physicians. Nonetheless, the sample of doctors used here was too small to permit any final conclusions. Further research in this field by selecting a larger sample of doctors would be welcome.

\section{ACKNOWLEDGEMENT}

To Professor Michael Shepherd, Dr. M. King, Dr. L. Rodrigues, Dr. B. Sen and Dr. G. Wilkinson for their comments or earlier versions of this paper. To Professor José da Silva Guedes, Professor of the "Faculdade de Ciências Médicas da Santa Casa de Misericórdia de São Paulo" and to Dr. Bernardo Lichewitz, Head of General Practice Unit of the "Hospital do Servidor Público Estadual de São Paulo", for allowing access to clinical facilities. To all the staff at Brasilandia, Servidor and Barra Funda for the help provided in the data collection, and also to Ana Ribeiro, who patiently administered the questionnaires.

MARI, J. de. J. et al. Distúrbios psiquiátricos e assistência primária à saúde no Brasil. Rev. Saúde públ., S. Paulo, 21:501-7, 1987.

RESUMO: Objetivou-se avaliar a habilidade de clínicos gerais em diagnosticar distúrbios emocionais na assistência primária, e investigar a possibilidade de se introduzir um questionário de "screening" para auxiliar o diagnóstico de doenças psiquiátricas. 0 estudo foi realizado em dois centros de saúde e um ambulatório de clínica geral na cidade de Săo Paulo (Brasil), por um período de 6 meses. Uma amostra representativa de pacientes adultos (16 anos) atendidos por clínico geral preencheu um questionário de "screening" para distúrbios psiquiátricos menores. Uma sub-amostra foi selecionada para entrevista psiquiátrica semi-estruturada, segundo a versão brasileira da "Clinical Interview Schedule" (CIS). No final da consulta os clínicos gerais avaliaram, através de uma escala padronizada, se o paciente apresentava ou não um distúrbio psiquiátrico e a severidade do mesmo. Considerável número de pacientes que apresentavam distúrbios psiquiátricos menores não foram identificados pelos clínicos gerais (de $22 \%$ a $79 \%$ ), sendo que o questionário de "screening" contribuiria sobremaneira na identificação desses distúrbios. São apresentadas quatro estratégias que podem ser consideradas na adoção do "screening", e discutidas as consequiências clínicas que circunscrevem a aplicação desse instrumental.

UNITERMOS: Distúrbios mentais, diagnóstico. Exames de massa, métodos. Cuidados primários de saúde. 


\section{REFERENCES}

1. BELLANTUONO, C.; FIORIO, R.; WILLIAMS, P.; CORTINA, P. Psychiatric morbidity in an Italian general practice. Psychol. Med., 1986. [In press].

2. BENJAMIN, S.; DECALMER, P.; HARAN, D. Community screening for mental illness: a validity study of the general health questionnaire. Brit. J. Psychiat, 140:174-80, 1982.

3. BRODATY, H.; ANDREWS, G.; KEHOEL, L. Psychiatric illness in general practice. I - Why is it missed? Aust. Fam. Physician, 8:625-31, 1982.

4. BUSNELLO, E. L.; LIMA, B.; BERTOLOTE, J. M. Aspectos interculturais de classificação e diagnóstico. J. bras. Psiquiat., 4:207-10, 1983.

5. CAMPILLO-SERRANO, C.; CARAVEO-ANDUAGA, J.; MORA, M. E. M.; LANZ, P. P. Confiabilidad entre clinicos utilizando la "Entrevista Estandarizada" de Goldberg en una versión mexicana. Acta psiquiatr, psicol. Amer. Lat., 27:44-53, 1981.

6. CHAN, D. W. \& CHAN, T. S. C. Reliability, validity and the structure of the general health questionnaire in a Chinese context. Psychol. Med., 13:363-71, 1983.

7. CHENG, T. A.; WILIIAMS, P.; CLARE, A. W. Reliability study of the clinical interview schedule between British and Chinese psychiatrics. Chin. Bull. Soc. Psychiat., 8: 54-5, 1982.

8. DHADPHALE, R.; ELIISON, R. H.; GRIFFIN, L. The frequency of psychiatric disorders among patients attending semi-urban and rural general out-patient clinics in Kenya. Brit. J. Psychiat., 142:379-83, 1983.

9. DIOP, B.; COLLIGNON, R.; GUEYE, M.; HARDING, T. W. Symptomatologie et diagnostic psychiatriques dans une region rurale du Senegal. Psychopathol. afric., 1:5-20, 1980.

10. EASTWOOD, M. R. Screening for psychiatric disorder. Psychol. Med., 1:197-208, 1971.

11. FERRAZ, M. P. T. \& MORAIS, M. F. Política de saúde mental: revisão dos dois últimos anos. Arq. Coord. Saúde mental, 45:11-22, 1985.

12. GOLDBERG, I. D.; BABIGLAN, H. M.; LOCKE, B. Z.; ROSEN, B. M. Role of nonpsychiatrist physicians in the delivery of mental health services: implications from three studies. Publ. Hlth Rep., 3:240-5, 1978.

13. GOLDBERG, D. P. \& BLACKWELL, B. Psychiatric illness in general practice: a detailed study using new methods of identification. Brit. med. J., 2:439-43, 1970.

14. GOLDBERG, D. P.; COOPER, B.; EASTWOOD, M. R.; KEDWARD, H. B.; SHEPHERD, M. A standardized psychiatric interview for use in community surveys. Brit. J. prev. soc. Med., 24:18-23, 1970.
15. GOLDBERG, D. P. \& HUXLEY, P. Mental illness in the community: the pathway to psychiatric care. London, Tavistock Publications, 1980.

16. GOLDBERG, D. P.; STEELE, J. J.; JOHNSON, A.; SMITH, C. Ability of primary care physicians to make accurate ratings of psychiatric symptoms. Arch. gen. Psychiat., 39: 829-33, 1982.

17. HARDING, T. W.; ARANGO, M. V.; BALTAZAR, J.; CLIMENT, C. E.; IBRAHIM, H. H. A.; IGNACIO, L. L.; MURTHY, R. S.; WIG, N. N. Mental disorders in primary health care: a study of their frequency and diagnosis in four developing countries. Psychol. Med., 10:231-41, 1980.

18. HARDING, T. W.; CLIMENT, C. E.; DIOP, M.; GIEL, R.; IBRAHIM, H. A.; MURTHY, R. S.; SULEIMAN, M. A.; WIG, N. N. The WHO collaborative study on strategies for extending mental health care. II: the development of new research methods. Amer. $J$. Psychiat., 140:1474-80, 1983.

19. HOBBS, P.; BALINGER, C. B.; SMITH, A. H. W. Factor analysis and validation of the general health questionnaire in women: a general practice survey. Brit. J. Psychiat., 142:257-64, 1983.

20. HOEPER, E. W.; NYCZ, G. R.; KESSLER, L. G.; BURKER JR., J, D. PIERCE, W. E. The usefulness of screening for mental illness. Lancet, 1:33-5, 1984.

21. IACOPONI, E.; AVANCINI, M. A.; NOTO, J. Ensino de psicologia médica em um ambulatório de medicina geral e familiar. Bol. Psiquiat., 17:130-6, 1984.

22. JOHNSTONE, A.; GOLDBERG, D. P. Psychiatric screening in general practice: a controlled trial. Lancet, 1:605-8, 1976.

23. KESSLER, L. G.; AMICK, B. C.; THOMPSOM, J. Factors influencing the diagnosis of mental disorder among primary care patients. Med. Care, 23:50-62, 1985.

24. KING, M. Case finding for at risk drinking in general practice: cost-benefit analysis. Psychol. Med., 16:359-63, 1986.

25. MARI, J. J. Minor psychiatric morbidity in three primary medical clinics in the city of São Paulo. London, 1986. [PhD Thesis University of London].

26. MARI. J. J. Minor psychiatric morbidity in three primary medical care clinics in the city of São Paulo: issues on the mental health of the urban poor. Soc. Psychiat., 22:129-38, 1987.

27. MARI, J. J.; BLAY, S. L.; IACOPONI, E. Um estudo de confiabilidade da versão brasileira da Clínical Interview Schelude. Bol. Ofic. sanit. panamer., 100:77-83, 1986. 
28. MARI, J. J. \& WILLIAMS, P. Estudo preliminar da confiabilidade da entrevista para estudos comunitários (EEC) de Goldberg e outros (1970) no Brasil. Rev. Ass. bras. Psiquiat., 5:173-6, 1983.

29. MARI, J. J. \& WILIIAMS, P. A comparison of the validity of two screening questionnaires (GHQ-12 and SRQ-20) in Brazil, using Relative Operating Characteristic (ROC) analysis. Psychol. Med., 15:651-9, 1985.

30. MARI, J. J. \& WILIAMS, P. A validity study of a psychiatric screening questionnaire (SRQ-20) in primary care in the city of São Paulo. Brit. J. Psychiat., 148:23-6, 1986.

31. MARKS, J. N.; GOLDBERG, D.; HILLIER, V. F. Determinants of the ability of general practitioners to detect psychiatric illness. Psychol. Med., 9:337-53, 1979.

32. SEN, B.; WILKINSON, G.; MARI, J. J. Psychiatric morbidity in primary health care: a two-stage screening procedure in developing countries. Cost-effectiveness and choice of instruments. Brit. J. Psychiat., 151:33-8, 1987.
33. SKUSE, D. \& WILLIAMS, P. Screening for psychiatric disorder in general practice. Psychol. Med., 14:365-77, 1984.

34. WEISTEIN, M. C. \& FINEBERG, H. V. Clinical decision analysis. Philadelphia, W. B. Saunders, 1980.

35. WILLIAMS, P. Mental illness and primary care: screening. In: Shepherd, M.; Wilkinson, G. \& Williams, P., ed., Mental llness in primary care setting. London, Tavistock Publications, 1986.

36. WILlIAMS, P. \& ClARE, A. Psychiatric in general practice. In: Hill, P.; Murray, R.; Thorley, A., ed. Essentials of postgraduate psychiatry. London, Grune \& Stratton Ltd., 1986.

37. WILKINSON, G. Mental health practices in primary care settings: an annotated bibliography, 1977-1985. London, Tavistock Publications, 1985.

Received for publication: 11/6/1987 Accepted for publication: 28/8/1987

\section{ANNEX}

The Portuguese Version of the Self Report Questionnaire (SRQ)*

Sim Não

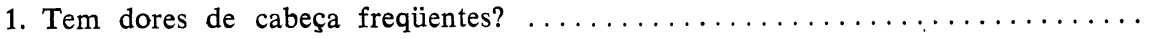

2. Tem falta de apetite?

3. Dorme mal?

4. Assusta-se com facilidade?

5. Tem tremores na mão?

6. Sente-se nervoso(a), tenso(a) ou preocupado(a)?

7. Tem má digestão?

8. Tem dificuldade de pensar com clareza?

9. Tem se sentido triste ultimamente?

10. Tem chorado mais do que de costume?

11. Encontra dificuldades para realizar com satisfação suas atividades diárias? .....

12. Tem dificuldades para tomar decisões?

13. Tem dificuldades no serviço (seu trabalho é penoso, lhe causa sofrimento?) ..

14. E incapaz de desempenhar um papel útil em sua vida?

15. Tem perdido o interesse pelas coisas?

16. Você se sente uma pessoa inútil, sem préstimo?

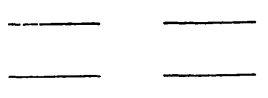

17. Tem tido a idéia de acabar com a vida?

18. Sente-se cansado(a) o tempo todo?

19. Tem sensações desagradáveis no estômago?

20. Você se cansa com facilidade?

* Harding ${ }^{17,18}(1980,1983)$. 